\title{
Should Turkey be Admitted into the European Union? The Debate
}

\author{
SOPHIE DI FRANCESCO-MAYOT ${ }^{1}$ \\ Monash European and EU Centre \\ s.difrancesco-mayot@pgrad.unimelb.edu.au
}

\begin{abstract}
Over the past decades, the European Union has witnessed an increasing apathy among European citizens' vis-à-vis EU institutions. In 1993, EU elites formally introduced the idea of a European citizenship' in an attempt on the one hand, to reactivate the European integration project, and, on the other hand, to foster greater consciousness of the European identity which the EU is supposed to represent. What opportunities and challenges would Turkey's accession to EU membership have on our idea of 'European citizenship' and identity'? An analysis on the current debate regarding Turkey's possible accession in the EU raises significant questions on the EU's identity and on the role of the EU in the international community.
\end{abstract}

The prospect of Turkish membership in the European Union (EU) has become one of the most politically contentious issues in Europe. Turkey's possible accession presents the EU with many challenges and opportunities and raises significant questions about the nature of the EU entity and about its future role in the international community. ${ }^{2}$ Is Turkey a European country? What is the nature of the EU entity? Will Turkey be an asset or a liability to the European Union? What are the economic, political, social and cultural implications of Turkish accession? Since October 2005, the European Commission and Turkish negotiators have looked systematically into the way Turkish legislation has adopted European law. ${ }^{3}$ Despite Turkey's institutional reforms which bring the country that much closer towards fulfilling the Copenhagen political criteria, 4 European politicians and civilians remain deeply divided on whether to offer EU membership to Turkey.

\footnotetext{
${ }^{1}$ Sophie Di Francesco-Mayot is a $\mathrm{PhD}$ candidate at the University of Melbourne. Her thesis explores the current crisis of social democracy/socialism in Europe. Sophie completed a BA (Global) in European and International studies in 2008 at Monash University and, completed a BA (HI Hons) in European politics at the European and EU Centre in 2009 with a thesis on the EU's present legitimacy crisis and the question of whether this increasing apathy reflects a sense of "Eurosceptiscim" among EU elites and citizens vis-à-vis the European integration project. During the course of her undergraduate degree, Sophie received the 2008 European Commission third-year prize in European studies as well as, the Dean's Recognition Award.

${ }^{2}$ H. Sjursen, Questioning EU Enlargement: Europe in search of identity, London, Routledge, 2006.

${ }^{3}$ C. Timmerman, D. Rochtus \& S. Mels, European and Turkish Voices in Favour and Against Turkish Accession to the European Union, Brussels, P.I.E. Peter Lang, 2008.

4 The 'Copenhagen Political Criteria' also known as the 'Copenhagen conditions' are a set of formal political requirements - established in 1993 by the European Council in Copenhagen - which determines whether a candidate country can join the European Union. The four criteria include: stability of institutions guaranteeing democracy, the rule of law, human rights and respect for and protection of minorities; the existence of a functioning market economy as well as the capacity to cope with competitive pressure and market forces within the Union; the ability to take on the obligations of membership including adherence to the aims of political, economic \& monetary union (M. Kesselman, J. Krieger, 'Introduction', in Kesselman et al. $5^{\text {th }}$ ed., European Politics in Transition, Boston and New York, Houghton Mifflin Company, 2008; and J. McCormick, Understanding The European Union: A Concise Introduction, $4^{\text {th }}$ ed., New York, Palgrave Macmillan, 2008).
} 
This paper utilises a threefold analytical approach based on 'utilitarian', 'moral' and 'ethical' arguments to examine the current debates for and against Turkey's admission to the European Union. It begins with a chronology of EU-Turkey relations from 1959 to 2005; followed by an account of the debate surrounding Turkey's accession. It then analyses the three main approaches: 'utilitarian', 'moral' 'ethical' which reflect a specific vision of the EU entity; this is followed by an examination on the position of the European Commission, the Turkey Parliament, the European public, the French and German elites, and the United States vis-à-vis Turkey EU membership. The role of the European Parliament in the enlargement process is discussed; and finally, future prospects for Turkey's entry into the EU will be explored.

\section{Turkey's Path to Europe}

EU-Turkish relations date back to the early stages of the European integration project. ${ }^{5}$ In 1959 - eight years after the establishment of the European Coal and Steel Community (ECSC) - Turkey applied for 'associate membership' in the European Economic Community (EEC), and on 12 September 1963 Turkey signed the 'Agreement Creating An Association Between The Republic of Turkey and the European Economic Community' commonly referred to as the 'Ankara Agreement' which came into effect in December 1964. The 'Ankara Agreement' sought to establish a Customs Union between the EEC and Turkey whilst also acknowledging the final goal of membership. ${ }^{6}$ Subsequently, in November 1970, the so-called 'Additional Protocol' established a timetable for the abolition of tariffs and quotas on goods traded between Turkey and the EEC. This mutual relationship — between Turkey and the European Community (EC) ${ }^{7}$ - was however temporarily stopped in the early 1980s due to Turkey's military coup which resulted in economic and political instability. ${ }^{8}$ In November 1983, following the establishment of a new Constitution by public referendum, EU-Turkish relations were fully restored. ${ }^{9}$ Moreover, in 1987 Turkey submitted its application for formal membership into the European Community. However, in 1989 - while confirming Ankara's eventual membership - the European Commission argued that Turkey's economic and political situation, as well as its poor relations with Greece and its ongoing conflict with Cyprus created an unfavourable environment to begin negotiations. ${ }^{10}$ Despite these setbacks, a Customs Union was established between the EU and Turkey in 1995 and in 1999, the Helsinki European Council officially recognized

\footnotetext{
${ }^{5}$ A. Lundgren, The Case of Turkey: Are Some Candidates more European than others', in H. Sjursen, op. cit.

${ }^{6}$ P. Kubick, Turkish Accession to the European Union: Challenges and Opportunities for the New Europe', Oakland University, USA, 2005.

${ }^{7}$ In 1957 two additional communities were created: the European Economic Community (EEC) establishing a customs union and the European Atomic Energy Community 'Euratom' for cooperation in developing nuclear energy. In 1967 ,the Merger Treaty created a single set of institutions for the three communities, which were collectively referred to as the European Communities, although more commonly just as the European Community 'EC' (Kesselman, op. cit., pp.39-45).

${ }^{8}$ M. Ugur \& N. Canefe, Turkey and European Integration: Accession prospects and issues, London, Routledge, 2004.

${ }^{9}$ L. McLaren, 'Explaining Opposition to Turkish Membership of the EU', European Union Politics, Vol.8, No.2, 2007, pp.251-278.

${ }^{10}$ F. Cameron, An Introduction to European Foreign Policy, New York, Routledge, 2007.
} 
Turkey as a candidate for membership. ${ }^{11}$ Finally, in December 2004 the European Council decided to start negotiations with Turkey which culminated in Turkey's official status as a candidate for full membership in October 2005.

\section{The Debate: Arguments "Pro" and "Con" Turkish Membership in the EU}

Despite Turkey's positive progression towards EU membership - evident in Turkey's important legal and constitutional reforms which continue to upgrade Turkish democracy in accordance with the Copenhagen political criteria - European and Turkish governments, political parties and citizens remain deeply divided on whether Turkey should become a member of the European Union. ${ }^{12}$ Proponents concentrate mainly on the strategic advantages that Turkish membership would have for the EU. Specifically, Turkey enthusiasts emphasize the geo-strategic importance of Turkey for the realisation of the Union's fundamental political interest in creating a secure and prospering neighbourhood. ${ }^{13}$ According to this analysis, Turkey's membership would eventually lead to a more politically stable, democratic and economically advanced Turkey. In summary, Turkey's EU membership would on the one hand, demonstrate that the Western style democracy and economic prosperity is achievable in a country with an overwhelmingly Muslim population, and on the other hand, it would strengthen the EU's co-operation on defence and security matters, particularly in dealing with Iran's nuclear threat and with Iraq's transition to a peaceful and democratic state. ${ }^{14}$ Furthermore, although identity arguments - cultural and religious - are utilised predominantly by those opposing Turkish accession, proponents assert that Turkey's membership would demonstrate the limitations of the "Clash of Civilisation" theory. ${ }^{15}$ Concurrently, it would highlight the fact that the EU is not limited to a 'Christian club'as purported by certain European conservatives including the Vatican - but that its values are open to all that want to apply. ${ }^{16}$ Indeed, it is contended that Turkey's integration in the EU would send a positive message to the rest of the world, particularly in the Middle Eastern region by demonstrating that democracy and Islam are compatible. Omer Taspinar - an expert on Turkey and the European Union maintains that Europe as a 'postmodern construct' should not be based on cultural and religious homogeneity but should instead, be based on multiculturalism, pluralism and democracy. ${ }^{17}$ Thus, supporters of Turkish EU membership state that Europe's identity should be defined according to the values it purports including liberty, solidarity, pluralism, tolerance and human rights as oppose to exclusionary ideas of culture and

\footnotetext{
${ }^{11} \mathrm{~F}$. Baban, 'European Identity in the Making?: Turkey in a Postnational Europe', paper presented to the Annual Meeting of Canadian Political Science Association, Canada, 2006.

12 A. Ruiz-J imenez \& J. Torreblanca, 'European Public Opinion and Turkey's Accession: Making Sense of Arguments For and Against', Working Paper, European Policy Institutes Network, 2007

${ }^{13}$ H. Kramer, 'Turkey and the EU: The EU's Perspective', lecture given at Network for European Studies, University of Helsinki, Finland, 2007.

14 Europe's World 2008, 'Arguments for and against Turkey joining the EU', , <http://www.europesworld.org>, accessed on $21^{\text {st }}$ May 2009.

${ }^{15}$ D. Senghaas, The Clash Within Civilisations: Coming to Terms with Cultural Conflicts, London, Routledge, 2001.

${ }^{16}$ EurActiv, Turkey in the EU: What the public thinks, EU News Policy Positions \& EU Actors online, 2009.

17 O. Taspinar, Kurdish Nationalism and Political Islam in Turkey, New York: Routledge, 2005.
} 
religion. Similarly, Turkey's accession — with approximately 80 million Turkish Muslims - according to Kramer, ${ }^{18}$ would provide a potential for the development of a genuine 'Euro-Islam' - based on mutual respect and understanding - which could further alienate Islamic radicalisation.

Differently, certain supporters of Turkish accession emphasise Turkey's economic potential as a potential asset to the EU. Although Turkey's present GDP in relation to its population size is low - unemployment in January 2009 increased by 1.59 million compared to the same period last year ${ }^{19}$ — adherents of this argument contend that Turkey's populous youthful population - compared to the EU's rapidly ageing population - would provide an excellent market for European goods and a potential source of labour. ${ }^{20}$ Indeed, statistics from Eurostat revealed that since the election of the pro-European 'AKP' political party headed by Prime Minister Erdogan, Turkey's GDP growth rate from 2002 to 2007 averaged $7.4 \%$ making it one of the fastest growing economies in the world during that period. ${ }^{21}$

In contrast, opponents to Turkish EU membership derive their arguments primarily from the conviction that Turkey is "too big, too poor and too Muslim". ${ }^{22}$ Critics argue that Turkey's population size of approximately 75,8 million would have wide-ranging implications on the power structure within the European institutions, with Turkey sending the largest number of MEPs into the European Parliament and gaining the most dominant position in the Council. ${ }^{23}$ Importantly, data from Eurostat 2007 predicted that if Turkey joined the EU in 2015, it would equal Germany's population of 82 million, and together they would account for $14 \%$ of the EU-28 population. ${ }^{24}$ In sum, Turkey's population size and rapid growth rate would have considerable influence in the population-based European parliament which critics argue, would alter the balance of power in the EU. Moreover, sceptics to Turkey's accession assert that Turkey's low percapita income and its significant agricultural sector - which employs about 33\% of the workforce compared with about 5\% of the EU-25 - would represent an enormous burden on the EU's budget particularly if major reforms of the Common Agricultural Policy (CAP) were not enforced. ${ }^{25}$ Evidently, an examination of Turkey's current economic demography indicates that Turkish membership would present significant challenges to the EU. With a per capita income of about $23 \%$ of the EU-15 and $27.5 \%$ of the EU-25, demographic prognosis predicts that it would take over 50 years for Turkey's income levels to equalise with those of the EU-15. ${ }^{26}$ In summary, according to this analysis, Turkey's population size, low GDP and its significant agricultural sector would

\footnotetext{
${ }^{18}$ Kramer, op.cit., pp.2-15.

${ }^{19}$ Turkish Statistics Institute, Turkey, 2009, <http:// www.turkstat.gov.tr/ OncekiGostergeler.do>, accessed 20 ${ }^{\text {th }}$ May 2009.

${ }^{20}$ W. Chislett, 'Socio-Economic Arguments For and Against Turkey's EU Membership', C. Timmerman, D. Rochtus \& S. Mels, op. cit.

${ }^{21} \mathrm{~F}$. Cameron, op. cit.

${ }^{22}$ K. Kirisci, 'Ts Turkey too Big, too Poor and too Different for the European Union', in C. Timmerman, D. Rochtus \& S. Mels, op. cit.; Kramer, op.cit., pp.2-20; M. Ugur \& N. Canefe, op.cit, pp.5-3; and Baban, op.cit., pp.1-15.

${ }^{23}$ EurActiv, EU urges Turkish reform push, EU News Policy Positions \& EU Actors online, 2009.

${ }^{24}$ Chislett, op.cit.,pp.73-81.

25 Ibid.

${ }^{26}$ D. Wood \& B. Yesilda, 'Institutional Dynamics in the European Union', The Emerging European Union, $4^{\text {th }}$ ed., New York, Pearson, 2007.
} 
complicate EU decision-making and place significant strain on the EU's regional development funds, as well as the CAP. ${ }^{27}$

Moreover, the EU's 'enlargement fatigue' has also been mentioned as a reason for opposing Turkish membership. Indeed, this idea is clearly expressed in Bolkestein's book The Limits of Europe, ${ }^{28}$ where he warns against European overstretch. Turkish accession, he argues, would reduce Europe to a glorified Customs Union and create risks for the European project. Turkey's large population size relative to its GDP would influence intra-European migration flows and thus, significantly alter the EU Parliamentary voting mechanisms creating a more Muslim Europe. ${ }^{29}$ Likewise, cultural and religious arguments have been employed by certain European conservatives as the basis for countering Turkish EU membership. Proponents emphasize Turkey's predominant Islamic culture and values as significantly different as the European Union's Christian-based heritage; and thus continue to perceive Turkey's culture and religion as 'Other' and therefore a threat to the EU's values and way of life. ${ }^{30}$

\section{Three Main Approaches Regarding Turkey's Accession}

The different debates - examined above - concerning Turkish accession in the EU, raise important questions including the nature of the EU entity, its future role in the international community, and how Turkey may or may not match those expectations. ${ }^{31}$ Will Turkey eventually join the EU? Which vision of the EU entity supports Turkey accession? Turkey's entry in the EU would have a significant symbolic impact in the Middle Eastern region as it would erode the artificial geographical divide between Europe and Turkey - a map that has often highlighted cultural differences - both real and imagined. 32 However, if Turkey's admission to the EU failed, it may lend credence to a competing exclusionary vision of Europe based on putative cultural homogeneity, and thus it would in part give added weight to a vision common in European media and public opinion of a civilisational divide between Turkey and the rest of Europe. ${ }^{33}$ In an attempt to understand the reasons underlying the different positions adopted by political elites and European citizens vis-à-vis Turkish European accession — discussed in the previous section - a threefold analytical approach based on 'utilitarian', 'moral' and 'ethical' arguments have been used. The three dimensions reflect a particular vision of the nature and role of the EU entity. ${ }^{34}$ According to Pat Cox - President of the European Parliament during 2002-2004 - Turkey's accession in the EU will depend on how European elites define Europe. 'Utilitarians' conceive the EU as a 'problemsolving' entity and thus, decisions on enlargement are assessed according to a 'cost-

\footnotetext{
27 EurActiv 2005, Turkey accession and Cyprus, EU News Policy Positions \& EU Actors online.

${ }^{28}$ F. Bolkestein, The Limits of Europe, Amsterdam, Lannoo Publishers, 2007.

29 C. Dahlman, Turkey's Accession to the European Union: The Geopolitics of Enlargement', Eurasian Geography and Economics, Vol.45, No.8, 2004, pp.353-574; and I. Karlsson, Turkey's Historical, Cultural and Religious Heritage: An Asset to the European Union?', in C. Timmerman, D. Rochtus \& S. Mels, 2008, op. cit.

${ }^{30}$ EurActiv, op.cit., p.2.

${ }^{31}$ Dalman, op.cit., p.554.

${ }^{32}$ D. Kostakopoulou, European Union Citizenship: Writing the Future, Manchester, University of Manchester Press, 1998.

33 Baban, op.cit, pp.1-11.

${ }^{34} \mathrm{H}$. Sjursen, op. cit.
} 
benefit analysis'.35 In comparison, 'moralists' see the EU as a 'value-based' geographically delimited entity where members share a strong sense of common identity, history, culture and traditions. According to this interpretation, decisions on enlargement are based on 'we-feelings' and/or 'kinship' and thus, the more a candidate is like the Member States in terms of geography, culture, history, the more likely its application will be supported. Finally, advocates of a 'rights-based' post-national EU entity, claim that universal principles and values including democracy, human rights and the rule of law, form the basis for a collective sense of identity and belonging. In this respect, the prospect of enlargement depends on the extent to which candidate countries share those values regardless of a high degree of cultural differences and traditions. ${ }^{36}$ From the three 'ideal conceptions' of the EU entity mentioned above, three hypotheses can be drawn:

H1 'Instrumental' support: The more Turkey accession is considered beneficial, the higher the support will be for accession; conversely, the more costly accession is perceived, the higher the opposition will be to enlargement. ${ }^{37}$

H2 'Tdentity' support: The more European citizens believe Turkey is part of Europe in terms of geography, history, and culture, the more they will support Turkish accession and vice versa. 38

H3 'Post-national' support: The more importance citizens assign to the set of shared principles on which the Union is based, and which conform to the enlargement acquis, the more likely their level of support for or opposition to Turkish membership will depend on whether they think Turkey meets or is in a position to meet these criteria. 39

Recent academic research including Dahlman's examination on the geopolitically implications of Turkish membership, Sjursen's investigation on the factors underlining European elites decision to accept or reject applicant countries into the EU, and Kubicek's analysis on the challenges and opportunities Turkish accession would bring to the EU entity, demonstrates that resistance to Turkish membership comes primarily from fears of the socio-economic consequences of Turkish membership as well as, the religious-cultural differences that exist between Turkey and the EU-27 member-states. ${ }^{40}$ More specifically, those who oppose Turkish membership are more likely to adopt a 'value-based' idea of the EU entity while proponents to Turkish membership perceive the EU as a predominantly 'right-based' post-national entity. Within this context, the question of whether Turkey will eventually attain full membership in the EU will largely

\footnotetext{
35 Ibid., pp.1-17.

36 P. Kubicek, 'Turkish Accession to the European Union: Challenges and Opportunities for the New Europe', Oakland University, USA, 2005,.

${ }^{37}$ Ruiz-J imenez \& Torreblanca, op. cit., p.4.

38 Ibid., p.5.

39 Ibid., p.6.

40 Dalman, op.cit., pp.353-574; H. Sjursen, op. cit.; and Kubicek, op.cit., pp.1-15.
} 
depend on how Europeans perceive the nature and future of the European Union in the global community. ${ }^{41}$

\section{Who is "For" and "Against" Turkey Accession?}

The European Commission has generally been a proponent for Turkish accession to the European Union. Despite several setbacks including the partial suspension of Turkish EU accession negotiations in December 2006 following Turkey's refusal to open its ports and airports to ships and planes from Cyprus, as well as, the appointment of two EU leaders — French President, Nicholas Sarkozy and German Chancellor, Angela Merkel — who are highly critical of Turkey's full EU membership, the Barroso Commission has undertaken constructive initiatives regarding EU-Turkey negotiations. ${ }^{42}$ In 2007, following the election victory of the pro-Islamic 'AKP' political party headed by Prime Minister Tayyip Erdogan, Barroso congratulated Erdogan stating that:

This comes at an important moment for the people of Turkey as the country moves forward with political and economic reforms. Prime Minister Erdogan has given his personal commitment to the sustained movement towards the EU. I wish him every success with his new mandate. ${ }^{43}$

Similarly, in response to Abdullah's Gul's victory as President of the Republic of Turkey, Javier Solana - EU High Representative for the CFSP — personally telephoned Gul stating the European Commission's continuing support in Turkish accession progress:

I would like to wish you every success in your new tasks and challenges. I am confident that your strong commitment and dedication as well as your highly valuable experience as Foreign Minister will be extremely helpful in this regard, and will contribute to broadening the reform process in Turkey and to strengthening regional stability. The European Union will continue to support you in these efforts... ${ }^{44}$

Moreover, the Commission's publication of yearly progress reports on Turkey is evidence of the European Commission's willingness to consider Turkey's membership. ${ }^{45}$ Furthermore, in January 2009, following a meeting in Brussels between Erdogan and the President of EU Commission, Barroso congratulated the country for its recent progress which, in December 2008, had led to the opening of two new chapters in accession negotiations. In particular, Barroso described the recent inauguration of a television channel broadcast entirely in Kurdish as a "historic development" for Turkey. Nevertheless, he encouraged Prime Minister Erdogan to pursue this work by relaunching reforms for modernising the country and by making progress on the Cypriot

\footnotetext{
${ }^{41}$ F. Keyman \& F. Baban, 'Turkey and the Postnational Europe: Challenges for the Emerging Political Community', paper presented to the Annual Meeting of International Studies Association, San Diego, USA, 2006.

42 EurActiv, op.cit.,pp.2-6.

43EurActiv 2007, Olli Rehn: Turkey membership 'vital' for EU, EU News Policy Positions \& EU Actors online, pp.1-2.

44 Europa, 'Delegation of the European Union to Turkey', Turkey, 2007,

$<$ http:// www.avrupa.info.tr/ News_Archieve/Agu_2007,29agu_3.html>, accessed 12 $2^{\text {th }}$ J une 2009.

45 T. Oguzlu, 'How to Interpret Turkey's Accession Process with the European Union? A Clash of Discourses', J ournal of International Affairs, Vol.7, No. 3, pp.1-19.
} 
question. Finally, President Barroso expressed his wish to see Turkey playing a key role in the energy issue by helping Europe to diversify its resources. ${ }^{46}$ Finally, in March 2009, President Barroso received President Gül at the Commission's headquarters in Brussels; again, Barroso stressed the Commission's full commitment to a constructive accession of negotiations:

Turkey and the EU have a long-term strategic bond. Security of energy supplies, the fight against terrorism, the global economic crisis, stability in the southern Caucasus, the Middle East peace process, just to mention a number of key issues on which we have common interests and where it is very much in the interest of the EU to work together with Turkey, and I believe also of Turkey to work together with the EU.

Furthermore, the Turkish Government has also supported Turkey's EU membership. Since August 2002, the Turkish parliament has made a number of important legal and constitutional changes to ameliorate Turkish democracy in accordance with the level of democracy in Europe. ${ }^{47}$ The 2003 election victory of the Turkish PM, Recept Tayyip Erdogan, and the subsequent appointment of the pro-EU Islamist 'Justice and Development Party' 'AKP' in 2007, reinforced Turkey's commitment to the European integration project. Turkey's active commitment towards becoming a member of the EU was reintegrated by Erdogan who claimed that "European values [are] Ankara's values". 48 In light of the significant cultural-religious arguments presented by EU elites and citizens against Turkish membership, Turkish adherents have countered such arguments by implicitly opting for a 'right-based' post-national conception of the EU. Indeed, in a speech presented to the European Commission in 2004, Erdogan stated that the EU needed Turkey for several reasons:

Turkey's strategic importance of the Eastern Mediterranean ... Turkey's full membership will re-enforce the desire and will for the co-habitation between Christians and Muslims ... The EU must recognise that it is a 'union of values', not a narrowly-defined geography or a union of rigidity. ${ }^{49}$

Despite general enthusiasm among EU and Turkish elites, the 2008 Eurobarometer poll showed that opposition to Turkey's EU membership among the EU population has risen steadily over the last decade, with over $50 \%$ of the European public opposing Turkish admission in the EU in 2005.50 What are the reasons for the extremely low levels of support for the prospect of Turkey's accession to the EU? Media and political discourses tend to point at different factors. The immediate and possible personal consequences of the enlargement process — job loss and the weakening of national cultures - are prominent factors which deter the European public towards supporting Turkish accession; meanwhile, the long- term benefits of Turkish membership - a boost in European economy and a stronger foreign policy particularly in terms of energy are impersonal and strategic long-term advantages and thus, have little impact on

\footnotetext{
${ }^{46} \mathrm{~J}$. Barroso, 'Press Speaking Points: Meeting with Abdullah Gul, President of Turkey', Brussels, 26 March, pp.1-2.

47 Keyman \& Baban, op.cit., p.1.

48 EurActiv, op.cit., pp.3-5.

49 EurActiv, op.cit., pp.4-7.

50 K. Barysch, 'What Europeans Think about Turkey and Why', Centre for European Reform, London, 2005.
} 
influencing the European public. 51 Moreover, European public attitudes on Turkish accession are largely formulated according to how an individual understands the future role of the EU entity as well as, how one conceives Turkey's accession whether as a question of foreign policy - as is the case for Spain and the UK - or primarily as a matter of internal EU or national politics - such as in France and Germany. The European public in France, Germany, Italy and Austria fear that Turkey's EU membership would signal the end of the federalists' dream of a political union as envisaged by the French protagonists J ean Monnet and Jacques Delors. ${ }^{2}$ In contrast, the British public - who since their accession in 1973 have overtly favoured economic integration over political integration - view Turkish accession more positively and focus on the ways in which Turkey's accession would benefit the EU economically and geo-strategically. Indeed, in September 2007, the former UK Foreign Secretary, David Miliband, stated that the EU "needs, as a clear goal, the inclusion of Turkey as a full member". Importantly, to understand the UK's strong support for Turkey EU membership, it is vital to highlight the fact that Turkey is a significant trading partner to the UK; in 2002, Britain was Turkey's largest export destination and the sixth largest import source. ${ }^{53}$ Finally, the 2008 Eurobarometer poll showed that supporters for Turkish accession adopted a predominantly 'rights-based' post-national vision of the EU while opponents to Turkish EU membership adopted a 'value-based' vision of the EU. Importantly, what these findings reveal is that the more the discourse on Turkey focuses on issues of culture, religion and identity, the more likely it is that support for Turkish membership will remain low; on the other hand, the more the discussion about Turkey is held and justified along post-national arguments, the more likely support for Turkish accession will be high. 54

The prospect of Turkish EU membership, has received significant opposition among French and German elites. In order to understand scepticism towards Turkish accession, national debates must be analysed. According to Veron cultural differences and the future balance of power in the enlarged Union are significant factors fuelling French opposition. ${ }^{55}$ The fact that France struggles to integrate its sizeable Muslim minority - the largest in Europe - has burdened the accession debate. These concerns are reinforced by the French President, Nicolas Sarkozy, who, during an interview with Charlie Rose - an American television interviewer and journalist — discussed the reasons behind his opposition to Turkey's Membership in the European Union. Turkey's geographical location - "Turkey is not in Europe, Turkey is in Asia Minor" - as well as its prominent Muslim culture - "Turkey has a different civilisational culture" — are prominent arguments presented by Sarkozy. ${ }^{56}$ Importantly, data from EurActiv revealed that among French people, and politicians in particular, there is a wide belief that their country's role in Europe has already weakened by previous enlargements and Turkey's

\footnotetext{
51 Ibid.,p. 2.

52 EurActiv, op.cit., pp.1-9.

${ }^{53}$ EurActiv, op.cit.,pp.1-6.

${ }^{54}$ A. Ruiz-J imenez \&J . Torreblanca, op.cit., pp.23-24.

55 Barysch, op.cit., p.3.
}

56 Youtube, 'Nicolas Sarkozy Talks With Charlie Rose', France, 2007, <http:// www.youtube.com/ watch?v=7TrNZremC_s>, accessed 23rd October 2008. 
accession would further dilute its influence.57 Similarly, Germany's issues on immigration and integration are also key ingredients fomenting opposition to Turkish membership. Germany is home to three million Turkish immigrants, many of whom do not come from Turkey's modern cities and region but from the backward south east regions of Turkey. ${ }^{58}$ Consequently, many Turkish immigrants have remained largely traditionalist and have failed to integrate in German society; indeed, since 1996, fortyfive honour killings by Turks on German soil have taken place. This in turn, has resulted in more than $90 \%$ of Germans' to believe that Islam is hostile and aggressive to women. ${ }^{59}$ German Chancellor, Angela Merkel's critical position towards Turkish EU membership is articulated in her 'defence of pacta sunt servanda' presented in 2006:

Turkey has been promised EU accession negotiations by a former German Government...while the CDU and I personally prefer a privileged partnership of Turkey to membership, we are still reliable partners... there should not be new promises on EU accession beyond the Balkans... we have to primarily focus on better EU integration in the face of recent enlargement rounds now... 60

In summary, when analysing the arguments presented by the current French President, Nicolas Sarkozy and the German Chancellor, Angela Merkel, against Turkish EU membership, it is evident that France and Germany have adopted a 'value-based' interpretation of the EU. Instead of encouraging Turkey EU membership, Merkel and Sarkozy propose a "privileged partnership" between Turkey and the EU which would enable the EU and Turkey to make the most out of economic advantages while limiting the impact of cultural and religious tensions.

\section{US Support for Turkey's EU Membership}

Unlike Germany and France, the United States has been a strong supporter for Turkish membership in the European Union since the beginning of EU-Turkish relations. Academic research on the motives underlining America's proactive support for Turkey EU membership reveals that Turkish-EU relations are seen largely through the prism of America's broader strategic interests. ${ }^{61}$ Indeed, during the Cold War, Turkey served as a bulwark against Soviet expansion to the Middle East and Mediterranean regions. Specifically, American scholars emphasise the fact that Turkey provided important facilities for monitoring Soviet compliance with arms control agreements. Moreover, Washington's support for Turkey's EU aspirations is demonstrated in their intensive lobbying efforts with key US allies — predominantly the UK — throughout the 1990s. ${ }^{62}$ Washington lobbied hard for the Customs Union in 1995 and for Turkey getting candidate status at Helsinki in 1999. Since 9/11, Turkey's role as a secular Muslim

\footnotetext{
57 EurActiv, op.cit., p.4.

58 EurActiv, op.cit., pp.3-4.

59 Barysch, op.cit, p.4.

60 A. Merkel, 'The German Turkey Debate Under: The Grand Coalition: State of the Debate', ESI European Stability Initiative, Germany, 2006.

61 S. Larrabee, 'American Perspectives on Turkey and Turkish-EU Relations', AICGS, J ohn Hopkins University, 2004, $<\mathrm{http}$ /// www.aicgs.org/ analysis/ c/ larrabee turkey.aspx>, accessed 23rd Ocotber 2009.

62 S. Sayari, 'The United States and Turkey's membership in the European Union', The Turkish YearBook, 2003, pp.168-176.
} 
democracy has taken on increased importance in US policy. Turkey has become the 'poster child' for the administration's effort to promote democracy in the Middle East through its initiative for the Broader Middle Eastern and North African region. ${ }^{63}$. Washington's emphasis on Turkey's strategic importance was reiterated in 2005 by American analysts who claimed that cementing Turkey's Western orientation and democratic political culture in the European Union would ensure the future strategic cooperation between the United States, Europe and Turkey. Similarly, in 2007, the Turkish Weekly ${ }^{64}$ stated that Turkey's entry to the EU would be critical for securing Turkey firmly to the West and defusing Huntington's notion of a "Clash of Civilisations". In J anuary 2008, George W. Bush stated that Turkey would act as a counterweight to fundamentalist Islam and would thus serves as a bridge between the West and the Islamic world. In April 2009, — during a news conference with Turkish President, Abdullah Gul — President Obama urged Turkey to help bridge the gap between the Muslim and Western worlds and stated that a stable and democratic Turkey was important for both the United States and to the world: "Turkey's future is in the European Union". 65

\section{Role of European Parliament}

Throughout the past decade, the European Parliament (EP) has become a key player in the European enlargement process. During the negotiation process, the EP has an important monitoring role. The EP's Committee on Foreign Affairs is responsible for coordinating the work on enlargement and ensuring consistency between the positions adopted by the Parliament and the activities of its Specialist Committees, as well as those of the J oint Parliamentary Committees. 66 The EP's most significant power in the enlargement process is to give its assent — Article 49 TEU — before any country joins the EU. This power is exercised only at the final stage once the negotiations have been completed. Moreover, as one of the two arms of the budgetary authority of the EU, the EP plays a predominant role with regard to the financial aspects of accession. ${ }^{67}$ As well as adopting resolutions on the progress of the candidates, the preparations and the conclusions of the European Council, the EP is involved in the following: MEPs meet on a regular basis with their counterparts from the candidate countries within the J oint Parliamentary Committees (J PC). The J PC meetings take place twice a year in order to exercise parliamentary oversight on all aspects of bilateral relations, and to examine in detail the progress in the accession preparation and negotiations. Furthermore, the various Specialist Committees of the EP are increasingly involved in monitoring the progress of negotiations in the policy areas for which they are responsible and the administrative capacity of the candidates to implement the EU acquis. Indeed, many

\footnotetext{
63 Larrabee, op.cit.

64 N. Danforth, 'A US Perspective on Turkish-EU Relations', Turkish Weekly, J uly 16, 2007, <

http:// www.turkishweekly.net/ op-ed/ 2262/ america-s-perspective-on-turkish-eu-relations.html

l pp.1-4, accessed 25 $5^{\text {th }}$ Aril, 2009

65 Spiegel Online, 'Obama Bashing in Bavaria and Paris', 2009,

<http:// www.spiegel.de/international/ europe/ 0,1518,druck-617868,00.html>, accessed 25th April 2009.

66 The EP has 20 standing Committees which are designed to aid the European Commission in initiating legislation. The Committees reflect the political makeup of the entire EP (F. Cameron, op. cit.).

67 European Parliament, '2003 Regular Report on Turkey's progress towards accession', Brussels, 2003, $<\mathrm{http}$ :// ec.europa.eu/ enlargement/archives/pdf/key_documents/2003/rr_tk_final_en.pdf>.
} 
committees have sent delegations on fact-finding missions to a number of the candidate countries and have organised hearings on specific issues. Moreover, within the Secretariat of the EP, the division responsible for the work with National parliaments co-operates regularly with its counterparts in the candidate countries. ${ }^{68}$ Thus, it is evident that the EP plays a significant role in the enlargement process. ${ }^{69}$ Importantly, through the Lisbon Treaty - currently waiting ratification - the European Parliament's legislative, budgetary and political influence will be extended thus, the EP's role in the European enlargement process will be extended and reinforced. ${ }^{70}$

\section{Future Prospects for Turkish Accession}

The question of Turkish accession presents the EU with many challenges and opportunities and raises significant questions about the nature of the EU entity and about its future role in the international community in the $21^{\text {st }}$ century. If Turkey is admitted to the European Union, it could serve as model for the Middle Eastern countries by demonstrating that democracy and Islam are not antagonists. Furthermore, Turkish membership would also reinforce the idea of the European Union as an entity that is built on the recognition of universal rights and values as oppose to exclusionary ideas of cultural and religious homogeneity. Several factors, including an individuals or member states understanding of the future role of the $\mathrm{EU}$ in the international community; a country's positive or negative experience with immigrants; and the actual/perceived economic, political, social and cultural benefits Turkey accession could bring to the EU, have been identified as influencing individuals and Member States' support or opposition to Turkey EU membership. The question of whether Turkey will attain full membership in the EU will largely depend on how individuals understand the nature and future of the European Union in the global community. The more the discourse on Turkey focuses on issues of culture, religion and identity, the more likely it is that support for Turkish membership will remain low. On the other hand, the more the discussion about Turkey accession is held and justified along post-national arguments, the more likely support for Turkish accession will be high. Finally, in light of the recent Central/ Eastern European enlargement, as well a, the current global financial crisis, the EU Member-States should focus on devising appropriate mechanisms to respond effectively to these challenges while continuing negotiation process with Turkey.

\footnotetext{
68 European Parliament, op. cit., pp.1-3.

69 Ibid., pp.1-3.

70 Y. Devuyst, The European Union's Institutional Balance After the Treaty of Lisbon: Community Method and Democratic Deficit Reassessed', Georgetown J ournal of International Law, Vol.39, No.2, 2008, pp.247-326.
} 